\title{
Transcriptional profiling of mammary gland in Holstein cows with extremely different milk protein and fat percentage using RNA sequencing
}

\author{
Xiaogang Cui ${ }^{1 \dagger}$, Yali Hou ${ }^{2 \dagger}$, Shaohua Yang ${ }^{1}$, Yan Xie ${ }^{1}$, Shengli Zhang ${ }^{1}$, Yuan Zhang ${ }^{1}$, Qin Zhang ${ }^{1}$, Xuemei Lu², \\ George E Liu ${ }^{3}$ and Dongxiao Sun ${ }^{*}$
}

\begin{abstract}
Background: Recently, RNA sequencing (RNA-seq) has rapidly emerged as a major transcriptome profiling system. Elucidation of the bovine mammary gland transcriptome by RNA-seq is essential for identifying candidate genes that contribute to milk composition traits in dairy cattle.

Results: We used massive, parallel, high-throughput, RNA-seq to generate the bovine transcriptome from the mammary glands of four lactating Holstein cows with extremely high and low phenotypic values of milk protein and fat percentage. In total, we obtained $48,967,376-75,572,578$ uniquely mapped reads that covered $82.25 \%$ of the current annotated transcripts, which represented 15549 mRNA transcripts, across all the four mammary gland samples. Among them, 31 differentially expressed genes $(p<0.05$, false discovery rate $q<0.05$ ) between the high and low groups of cows were revealed. Gene ontology and pathway analysis demonstrated that the 31 differently expressed genes were enriched in specific biological processes with regard to protein metabolism, fat metabolism, and mammary gland development $(p<0.05)$. Integrated analysis of differential gene expression, previously reported quantitative trait loci, and genome-wide association studies indicated that TRIB3, SAA (SAA1, SAA3, and M-SAA3.2), VEGFA, PTHLH, and RPL23A were the most promising candidate genes affecting milk protein and fat percentage.
\end{abstract}

Conclusions: This study investigated the complexity of the mammary gland transcriptome in dairy cattle using RNA-seq. Integrated analysis of differential gene expression and the reported quantitative trait loci and genome-wide association study data permitted the identification of candidate key genes for milk composition traits.

Keywords: Transcriptome, Differentially expressed gene, Mammary gland, Protein percentage, Fat percentage, RNA-Seq, Dairy cattle

\section{Background}

In dairy cattle, milk yield and milk components are two of the most important economic traits. DNA-based markerassisted selection has certain advantages over the traditional dairy cattle breeding programs, such as shortening of the generation interval and enhancing the selection accuracy of young bulls, by incorporating detected

\footnotetext{
*Correspondence: sundx@cau.edu.cn

${ }^{\dagger}$ Equal contributors

'Key Laboratory of Animal Genetics and Breeding of Ministry of Agriculture, National Engineering Laboratory of Animal Breeding, College of Animal Science and Technology, China Agricultural University, Beijing 100193, China Full list of author information is available at the end of the article
}

quantitative trait loci (QTLs) into the genetic evaluation. Therefore, since the first report by Georges et al. [1], extensive QTL mapping has been implemented to detect QTLs with large effects on milk production traits. As of August 23, 2013, 422, 823, and 648 QTLs for milk yield, milk protein, and milk fat have been reported via markerQTL linkage analysis (LA) and/or linkage disequilibrium (LD) (http://www.animalgenome.org/cattle/). Most recently, as a powerful tool for revealing the genetic basis of complex traits, several genome-wide association studies (GWASs) were conducted to map QTLs for milk yield and composition traits in dairy cattle [2-11]. To date,

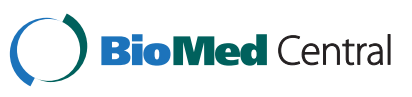


these two approaches have detected a large number of significant chromosome segments and genetic associations with milk yield and composition, which include two confirmed causal mutations: DGAT1p.Lys232Ala and GHR p.Phe279Tyr [2-13].

Besides genetic data, gene expression profiles and metabolic pathway analysis offer new opportunities to elucidate the underlying mechanisms of complex traits in humans and farm animals. Recently, along with the rapid development and cost reduction of next generation sequencing (NGS), sequence-based assays of transcriptomes, namely RNA sequencing (RNA-seq), have become a comprehensive and accurate tool for gene expression pattern analyses. As compared with microarray technology, RNA-seq enables analysis of the complexity of whole eukaryotic transcriptomes with less bias, greater dynamic range, lower frequency of false-positive signals, and higher reproducibility $[14,15]$. There have been several studies on the bovine transcriptome using RNA-seq techniques, such as the bovine embryo and milk transcriptome [16-21]; however, no studies on the bovine mammary gland transcriptome by RNA-seq have been published. Two studies on the transcriptome of the mammary gland of Holstein cows using an oligonucleotide microarray have been presented, one of which compared the gene expression profile before (dry) and after (milk) parturition, using an Affymetrix cDNA array [22]. The other performed functional analyses of differentially expressed gene patterns across $-30,-15,1,15$, $30,60,120,240$, and 300 days relative to parturition with microarray [23]. In the present study, we used RNA-seq technology to examine the genome-wide gene expression profile in mammary glands between two groups of Holstein cows with extremely high and low milk protein percentage (PP) and fat percentage (FP). We then integrated the analysis of the differentially expressed genes detected in this work and the previously reported QTLs and GWAS data to identify key genes affecting milk protein and FP.

\section{Methods}

Animals and mammary gland tissue sample collection

Four lactating Chinese Holstein cows in their 2nd/3rd lactation, from different families, were selected from among 30,000 Holstein cows fed in the Beijing Sanyuanlvhe Dairy Farming Center. The selection was based on their monthly test-day milk PP and FP records for the current lactation and previous lactation(s), which were provided by the Dairy Data Center of China. The average PP and FP was 3.1\% $(2.7-3.8 \%)$ and $3.6 \%(3.1-4.5 \%)$ in this population. To keep the environment factors identical, four cows that were in almost the same period of lactation $(353,341,377$, and 325 days in milk of the 2nd, 3rd, 2nd, and 3rd lactations, respectively) and collected from the same farm, which possesses 800 Holstein cows in total. According to the last PP and FP record of the current lactation, four cows were divided into two groups with extremes of the phenotypic values for PP and FP: two cows (high group) had high PP (3.6\% and 3.8\%) and FP (3.9\% and 4.5\%); the other two cows (low group) showed low PP $(3.0 \%, 2.9 \%)$ and FP (3.2\%, 3.1\%).

The cows were killed by electroshock, bled, skinned, and dismembered in the same slaughterhouse. The rear mammary gland from each individual was removed within 30 min after slaughter. The right rear quarter of the mammary gland was cut in half lengthways from the teat such that white mammary ducts and pink epithelium tissue were clearly observed and some milk flowed out. Five pieces of epithelium tissue samples per cow were carefully collected for RNA isolation, placed into a clean RNAsefree Eppendorf tube, and stored in liquid nitrogen. All sample collection procedures were carried out in strict accordance with the protocol approved by the Animal Welfare Committee of China Agricultural University (Permit Number: DK996).

Considering the large genetic effect of the DGAT1 gene on milk composition traits, these four cows were genotyped on the DGAT1p.Lys232Ala mutation. A pair of primers [24] was used to amplify a 201-bp fragment comprising DGAT1 p.Lys232Ala. Forty microliters of polymerase chain reaction products of each individual were directly sequenced using an ABI3730XL sequencer (Applied Biosystems, CA, USA). As a result, the genotypes of the cows with high PP and FP and cows with low PP and FP on DGAT1p.Lys232Ala were identified to be KA, KA, KA, and AA, respectively (Additional file 1: Figure $\mathrm{S} 1$ ). The allele $\mathrm{K}$ has been reported to be associated with increased FP and PP [25,26].

\section{RNA isolation and quality assessment}

The TRIzol reagent (Invitrogen, Carlsbad, CA) was used to extract total RNA from mammary epithelium samples. RNase-free DNase I (New England Biolabs) was used to remove DNA contamination from the RNA by incubating for $30 \mathrm{~min}$ at $37^{\circ} \mathrm{C}$. One piece of the five samples from each cow was randomly chosen for RNA isolation. The average RNA yield from each sample was around $73 \mu \mathrm{g}$ from $100 \mathrm{mg}$ of tissue. RNA degradation and contamination was monitored on $1 \%$ agarose gels. A NanoPhotometer $^{\oplus}$ spectrophotometer (Implen, CA, USA) was used to check RNA purity. A Qubit ${ }^{\circ}$ RNA Assay Kit in Qubit ${ }^{\circ}$ 2.0 Fluorometer (Life Technologies, CA, USA) measured the RNA concentration and the RNA Nano 6000 Assay Kit of the Bioanalyzer 2100 system (Agilent Technologies, CA, USA) assessed the RNA integrity.

\section{Transcriptome sample preparation, clustering, and re-sequencing}

A total of $3 \mu \mathrm{g}$ of RNA per sample per cow was used as the input material for the RNA sample preparations. 
The RNA integrity number (RIN) values of the two samples from cows with high milk PP and FP and two samples from the cows with low PP and FP were $7.0,7.5,7.2$, and 7.5, respectively. Sequencing libraries were generated using IlluminaTruSeq ${ }^{\text {Ti }}$ RNA Sample Preparation Kit (Illumina, San Diego, CA, USA), following manufacturer's recommendations. Four index codes were added to attribute sequences to each sample. Briefly, poly-T oligo-attached magnetic beads purified the mRNA from total RNA. Divalent cations under elevated temperature in an Illumina proprietary fragmentation buffer then fragmented the mRNAs. Random oligonucleotides and SuperScript II were used to synthesize first-strand cDNA. DNA polymerase I and RNase $\mathrm{H}$ subsequently generated second-strand cDNA. Exonuclease/polymerase activities were used to convert remaining overhangs to blunt ends and to remove enzymes. After adenylation of 3' ends of DNA fragments, Illumina PE adapter oligonucleotides were ligated to prepare for hybridization. To select cDNA fragments approximately $200 \mathrm{bp}$ in length, the library fragments were purified with AMPure XP system (Beckman Coulter, Beverly, USA). An Illumina polymerase chain reaction (PCR) Primer Cocktail in a 10-cycle PCR reaction selectively enriched DNA fragments with ligated adaptor molecules on both ends. The AMPure XP system purified the products, which were quantified using the Agilent high-sensitivity DNA assay on the Agilent Bioanalyzer 2100 system.

A cBot Cluster Generation System, using TruSeq PE Cluster Kit v3-cBot-HS (Illumina) according to the manufacturer's instructions, clustered the index-coded samples. After cluster generation, an Illumina Hiseq 2000 platform sequenced the libraries, generating around 268 million 100-bp paired-end reads in total.

\section{Quality control for paired-end reads}

Raw data (raw reads) formatted as fastq were processed through our self-written perl scripts. In this step, clean data (clean reads) were obtained by removing reads containing adapters, reads containing at least $10 \mathrm{Ns,} \mathrm{and}$ low-quality reads (more than half of the reads having a phred base quality score of less than 5) from the raw data. After that, the description statistics for the clean data, such as Q20 (the proportion of bases with a phred base quality score greater than 20; i.e., the proportion of read bases whose error rate is less than 1\%), Q30 (the proportion of bases with a phred base quality score greater than 30; i.e., the proportion of read bases whose error rate is less than $0.1 \%$ ), GC content, and sequence duplication level of the clean data were calculated (Additional file 2: Table S1). All the downstream analyses were based on the clean data.

\section{Reads alignment to the bovine reference genome and annotated transcripts}

The Cattle reference genome (UMD3.1.66) and corresponding gene model annotation files were downloaded directly from the cow genome website (ftp://ftp.ensembl. org/pub/release-69/fasta/bos_taurus/dna/). An index of the reference genome was built using Bowtie v0.12.8 and paired-end clean reads for each individual were aligned to the reference genome by TopHat v2.0.0 (http://tophat. cbcb.umd.edu/). The detailed alignment information is presented in Additional file 2: Table S1, including total numbers of reads, mapped reads, and unique mapped reads.

\section{Identification of differentially expressed genes}

The numbers of RNA-seq reads produced from a transcript is directly proportional to its abundance; therefore, the gene expression level could be quantified by the reads count. Commonly used Cuffdiff [27] and DESeq [28] methods identified the differentially expressed genes between the different groups.

For Cuffdiff, the commonly used fragments per kilobase of transcript per million mapped fragments (FPKM) value [29] in pair-end sequencing experiments incorporated two normalization steps; i.e., the number of fragments was normalized by the transcript's length and the total yield of the fragments to ensure accurate quantification of the gene's expression [27]. TopHat's read alignments were assembled by Cufflinks [27], and then the differentially expressed genes and transcripts across Holstein cows with high and low PP and FP were detected and quantified by Cuffdiff, which is included in the Cufflinks package, using a rigorous sophisticated statistical analysis [27]. Negative binomial distribution was introduced to address the gene expression (counts) modeling for single-isoform genes and a mixed model of negative binomials using the beta distribution parameters as the mixture weights, followed by a t-test for defined statistics, to identify the significantly differentially expressed genes [30]. The differentially expressed genes, their corresponding attributes, fold changes (in $\log _{2}$ scale), $p$-values, and $q$-values (false discovery rate corrected $p$ values) were reported in the output files from Cuffdiff. The significance of the gene expression difference was determined as yes if the $p$-value was less than the false discovery rate after Benjamini-Hochberg correction for multiple testing (http:// cufflinks.cbcb.umd.edu/manual.html). In addition, to filter out those alignments that lie within intronic intervals implied by the spliced alignments, we set the pre-mrnafraction as 0.25 .

For the DESeq method, differentially expressed genes were detected by using the Deseq $\mathrm{R}$ package (1.8.3). DESeq allows the accurate comparisons between extreme cow groups by normalizing the number of reads, 
which accommodates a scaling factor for a given cow by computing the median of the ratio, for each gene, of its read count over its geometric mean across all cows [30]. Negative binomial distribution was introduced to address the gene expression (counts) modeling, and the Fisher's exact test was adopted to test the significantly differential expressed genes. The $p$-values were adjusted using the Benjamini and Hochberg method. A corrected $p$-value of 0.05 was set as the threshold for significant differential expression.

\section{$\mathrm{GO}$ and gene functional analysis of differentially expressed genes}

The Goseq R package implemented gene ontology (GO) enrichment analysis of the differentially expressed genes, in which gene length bias was corrected. GO terms with corrected $p$-values less than 0.05 were considered significantly enriched among the differential expressed genes.

In addition, Ingenuity Pathways Analysis (IPA) software v9.0 (http://www.ingenuity.com/, Ingenuity Systems, Redwood City, CA) was used to analyze the differentially expressed genes between cows with high and low PP and FP. The accessions of these genes were imported into IPA, then the "Core Analysis" function included in IPA was used to analyze the genes in the context of networks, biological functions, and canonical pathways. The detailed information concerning IPA analyses was published previously [31,32].

\section{Real-time quantitative reverse-transcription-PCR (qRT-PCR)}

To validate the repeatability and reproducibility of gene expression data obtained by RNA sequencing in Holstein cows, qRT-PCR was carried out on 11 randomly selected differentially expressed genes using the total RNA used for RNA-seq. Superscript II reverse transcriptase (Invitrogen, Carlsbad, CA) synthesized first-strand cDNA. Primer3 (http://fokker.wi.mit.edu/primer3/input. $\mathrm{htm}$ ) designed gene-specific primers, which were validated using Oligo 6.0. Primer sequences are shown in Additional file 3: Table S2. The mRNA levels of the differentially expressed genes were normalized against two housekeeping genes, GAPDH and $A C T B$, in the corresponding samples. qRT-PCR was carried out in triplicate with the DyNAmo SYBR Green PCR kit (Applied Biosystems Inc.) on a LightCycler480 (Roche Applied Science, Penzberg, Germany), using the following program: $95^{\circ} \mathrm{C}$ for $10 \mathrm{~min}$; 45 cycles of $95^{\circ} \mathrm{C}$ for $10 \mathrm{~s}, 60^{\circ} \mathrm{C}$ for $10 \mathrm{~s}$, and $72^{\circ} \mathrm{C}$ for $10 \mathrm{~s}$; $72^{\circ} \mathrm{C}$ for $6 \mathrm{~min}$.

\section{Results}

Sequencing and mapping of the bovine mammary gland transcriptome

We sequenced cDNA libraries of four mammary epithelium samples from two Holstein cows with higher milk
PP and FP and two with lower phenotypic values. In total, we acquired 53,294,906-83,019,642 paired-end reads of $100 \mathrm{bp}$ in length per sample. As a result, the total read length was 26.6 gigabases $(\mathrm{Gb})$ for the four samples. Alignment of the sequence reads against the bovine genome UMD3.1.66 yielded 90.6-91.9\% of uniquely aligned reads across the four samples, of which $80-85 \%$ fell in annotated exons, $4-6 \%$ were located in introns, and the remaining $11-14 \%$ was assigned to intergenic regions. Unmapped or multi-position matched reads (8.1-9.4\%) were excluded from further analyses (Additional file 2: Table S1). Consequently, 15549 mRNA transcripts were detected as expressed in the four mammary gland samples, among which there were certain well-known genes affecting milk traits; e.g., K-casein (CSN3), $\beta$-casein (CSN2), a-lactalbumin (LALBA), $\beta$-lactoglobulin (BLG), DGAT1, GHR, STAT5A, STAT5B, and SCD. These results further confirmed the reliability of RNA-seq and the sampling accuracy of the mammary gland tissue used in this study. Furthermore, using a pairwise approach, two cows in the same group were used to eliminate the background noise of individual-specific transcription, enabling acquisition of more relevant data from the two groups. The correlation coefficient $\left(R^{2}\right)$ between the two individuals within the high and low groups for milk PP and FP was calculated based on the fragments per kilobase of transcript per million mapped fragment (FRPM value) of each cow and was shown to be 0.986 and 0.983 , respectively, indicating that the similarity of the two biological replicates within each group was sufficiently high (Additional file 4: Figure S2).

\section{Differential gene expression between high and low groups for milk PP and FP}

Using DEseq and Cuffdiff methods, the differential gene expression profile between the Holstein cows with the higher and lower PP and FP was examined. In total, 31 top half expressed genes were detected as significantly different by DEseq, among which six genes were also identified by Cuffdiff $(p<0.05$, FDR $q<0.05)$. The expression levels of 28 of the 31 genes were downregulated in the cows with higher PP and FP; the other three genes showed higher expression in the cows with lower PP and FP. Details of differentially expressed genes, their full names, as well as $p$ - and $q$-values, are shown in Table 1 and Figure 1.

Furthermore, we randomly selected 11 differentially expressed genes, including SAA3, TRIB3, SESN2, CHAC1, SAA1, ATF3, ARID1B, PTHLH, ZC3H14, H4, and DDIT3, to perform expression patterns validation using qRT-PCR. For these selected 11 genes, the correlations between the mRNA expression level from qRT-PCR and RNA-seq were relatively high, with correlation coefficients of 0.81 and 0.82 , which were normalized by housekeeping genes $G A P D H$ and $A C T B$, respectively, confirming the high 
Table 1 Thirty-one differentially expressed transcripts between the mammary gland of two cows with high milk protein and fat percentage and two cows with low protein and fat percentage

\begin{tabular}{|c|c|c|c|c|c|c|}
\hline $\begin{array}{l}\text { Transcript } \\
\text { symbol }\end{array}$ & NCBI gene ID & Description & $\begin{array}{c}\log _{2} \text { fold change } \\
\text { (high/low) }\end{array}$ & $\mathrm{p}$ value & FDR q value & Detected by \\
\hline SAA3 & 281474 & Serum amyloid A3 & -2.09 & $9.90 \mathrm{E}-11$ & $1.47 \mathrm{E}-07$ & DEseq \\
\hline HEATR7B2 & 518808 & HEAT repeat family member 7B2 & 3.49 & $8.36 \mathrm{E}-10$ & $1.04 \mathrm{E}-06$ & DEseq \\
\hline CABPA & 281651 & Complement component 4 binding protein, alpha & -1.57 & 9.20E-10 & $1.04 \mathrm{E}-06$ & DEseq \\
\hline TRIB3 & 538465 & Tribbles homolog 3 & -2.64 & $3.38 \mathrm{E}-08$ & $2.63 \mathrm{E}-05$ & DEseq, Cuffdiff \\
\hline SESN2 & 509863 & Sestrin 2 & -3.01 & 4.08E-08 & 2.99E-05 & DEseq, Cuffdiff \\
\hline $\mathrm{CHACl}$ & 505991 & Cation transport regulator homolog 1 & -2.86 & $8.62 \mathrm{E}-08$ & 5.97E-05 & DEseq, Cuffdiff \\
\hline HSPD1 & 511913 & Heat shock 60 kD protein 1 & -0.57 & $1.12 \mathrm{E}-07$ & 7.35E-05 & DEseq \\
\hline SLC25A38 & 512325 & Solute carrier family 25 member 38 & -0.70 & $1.57 \mathrm{E}-07$ & $9.80 \mathrm{E}-05$ & DEseq \\
\hline NR4A1 & 528390 & Nuclear receptor subfamily 4, group A, member 1 & 2.42 & 4.10E-07 & 0.000243 & DEseq \\
\hline$B M X$ & 531514 & BMX non-receptor tyrosine kinase & 2.92 & 6.94E-07 & 0.000393 & DEseq \\
\hline SAA1 & 616035 & Serum amyloid A1 & -5.84 & 9.99E-07 & 0.000541 & DEseq, Cuffdiff \\
\hline ATF3 & 515266 & Activating transcription factor 3 & -2.70 & 1.24E-06 & 0.000641 & DEseq, Cuffdiff \\
\hline RPL23A & 507168 & Ribosomal protein L23a & -5.31 & $1.88 \mathrm{E}-05$ & 0.038988 & DEseq, Cuffdiff \\
\hline $\mathrm{CDH} 16$ & 508777 & Cadherin $16, \mathrm{KSP}$-cadherin & -1.27 & $1.29 \mathrm{E}-06$ & 0.000641 & DEseq \\
\hline VEGFA & 281572 & Vascular endothelial growth factor A & -1.25 & 1.35E-06 & 0.000647 & DEseq \\
\hline KRT24 & 788424 & Keratin 24 & -1.83 & $6.96 \mathrm{E}-06$ & 0.003095 & DEseq \\
\hline EIF4G3 & 534618 & Eukaryotic translation initiation factor 4 gamma, 3 & -0.49 & 9.76E-06 & 0.004052 & DEseq \\
\hline CDKNIA & 513497 & Cyclin-dependent kinase inhibitor $1 \mathrm{~A}$ & -2.20 & $1.22 \mathrm{E}-05$ & 0.004742 & DEseq \\
\hline$B O L A-D Q B$ & 282495 & Major histocompatibility complex, class II, DQ beta & -6.92 & $1.21 \mathrm{E}-05$ & 0.004742 & DEseq \\
\hline$A R I D 1 B$ & 505229 & AT rich interactive domain 1B (SWI1-like) & -0.70 & 1.46E-05 & 0.005502 & DEseq \\
\hline PTHLH & 286767 & Parathyroid hormone-like hormone & -0.76 & 1.69E-05 & 0.006194 & DEseq \\
\hline ZC3H14 & 511473 & Zinc finger CCCH-type containing 14 & -0.65 & 1.99E-05 & 0.007094 & DEseq \\
\hline $\mathrm{H} 4$ & 280691 & Histone $\mathrm{H} 4$ & -2.17 & 2.07E-05 & 0.007179 & DEseq \\
\hline FAM71A & 616153 & Family with sequence similarity 71 , member $A$ & -1.0 & 2.53E-05 & 0.008504 & DEseq \\
\hline THBS4 & 541281 & Thrombospondin 4 & -2.10 & $3.21 \mathrm{E}-05$ & 0.010249 & DEseq \\
\hline DDIT3 & 777788 & DNA-damage-inducible transcript 3 & -1.70 & 4.01E-05 & 0.012494 & DEseq \\
\hline M-SAA3.2 & 618238 & Mammary serum amyloid A3.2 & -2.49 & 4.39E-05 & 0.013339 & DEseq \\
\hline HISTIHZAC & 506900 & Histone cluster 1, H2ac & -2.01 & 5.54E-05 & 0.016423 & DEseq \\
\hline FCAMR & 100297408 & Fc receptor, IgA, IgM, high affinity & -2.42 & $6.43 \mathrm{E}-05$ & 0.018621 & DEseq \\
\hline DNER & 516825 & Delta/notch-like EGF repeat containing & -1.0 & 8.29E-05 & 0.023475 & DEseq \\
\hline P4HA2 & 507327 & Prolyl 4-hydroxylase, alpha polypeptide II & -0.69 & 9.24E-05 & 0.025587 & DEseq \\
\hline
\end{tabular}

reproducibility of RNA-seq data in this study (Additional file 5: Figure S3).

\section{Gene Ontology enrichment and pathway analysis}

To further investigate the functional associations of the 31 genes differentially expressed genes, we performed the gene ontology (GO) analysis at the GO database (http://www.geneontology.org/GO.database.shtml). Several significant GO categories were enriched $(p<0.01)$, including GO processes related to protein and lipid metabolism, mammary gland development, differentiation, and immune function. Such biological processes were involved in high-density lipoprotein particles, export of cholesterol, protein refolding, ubiquitin-protein ligase regulator activity, angiogenesis of vascular endothelial and epithelial cell, cell viability/death/differentiation, mammary gland bud elongation, lipopolysaccharide receptor complex, regulation of MAP kinase activity, and activation of immune-related cells (Table 2).

At the same time, we also performed metabolic pathway analysis on the 31 differentially expressed genes using Ingenuity Pathways Analysis (IPA) software v 9.0. A significant molecular function involving "lipid metabolism" was enriched. Three genes, TRIB3, SAA1, and $A T F 3$, were found to be involved in the lipid metabolism pathway $(p<0.05)$, which is mostly related to the 


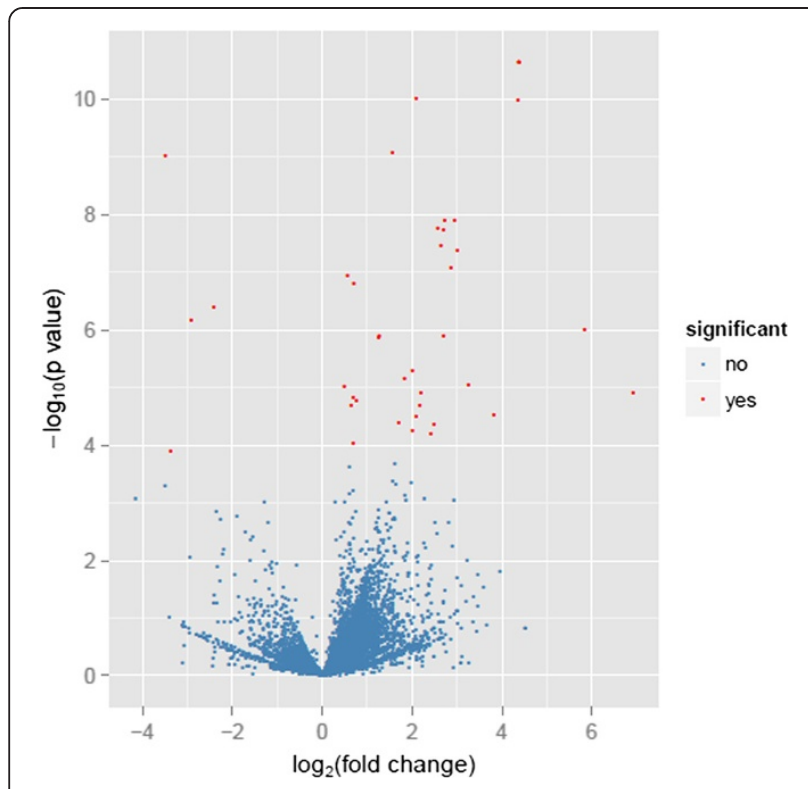

Figure 1 Volcano plot displaying differential expressed genes between the mammary glands of two cows with high milk PP and FP and two cows with low PP and FP. The $y$-axis corresponds to the mean expression value of $\log _{10}(p$-value), and the $x$-axis displays the $\log 2$ fold change value. The red dots represent the significantly differentially expressed transcripts $(p<0.05$, false discovery rate $(F D R) q<0.05$ ) between two cows with high milk PP and FP and two cows with low PP and FP; the blue dots represent the transcripts whose expression levels did not reach statistical significance $(p>0.05$, FDR $q>0.05)$ between the high and low groups.

formation of milk fat traits. The detailed list of the genes and their functional annotations are shown in Table 3.

\section{Integrated analysis of RNA-seq, QTL, and GWAS data}

To gain further insights into the association of the 31 differentially expressed genes with milk composition traits, we integrated the 31 genes and previously reported QTL mapping and GWAS data by comparing their chromosome positions with those of the QTLs (http://www.animalgenome.org/cgi-bin/QTLdb) and the significant SNPs detected by GWAS for milk production traits. The positions of the 31 genes on the chromosomes and detailed information about the nearest QTLs and significant SNPs are shown in Tables 4 and 5.

Among the 31 differentially expressed genes, 17 were found to be located within QTL regions that were confirmed to have large genetic effects on milk PP and FP, including SAA3 (12.6 cM), HEATR7B2 $(0.2 \sim 6.3 \mathrm{cM})$, TRIB3 (5.0 5.2 cM), SESN2 (14.6 cM), HSPD1 $(6.5 \mathrm{cM})$, NR4A1 (12.1 cM), SAA1 (11.6 cM), RPL23A (5.8 8.4 cM), VEGFA (2.5 cM), KRT24 (0.8 4.1 cM), CDKN1A (12.4 cM), BoLA-DQB (4.7 9.9 cM), PTHLH (1.1 $11.6 \mathrm{cM})$, H4 (3.9 cM), DDIT3 (28.4 cM), M-SAA3.2 (13.6 cM), and HIST1H2AC (3.8 cM).
On the other hand, 21 genes were found to be within $23.2 \mathrm{~Kb}$ to $9.9 \mathrm{Mb}$ of one or multiple significant SNPs for milk PP and FP detected in previous GWASs in dairy cattle (Table 5).

Combining the QTL and GWAS data, 14 genes were near to both the peak locations of the reported QTLs and significant SNPs for PP and FP, including $S A A 3$, HEATR7B2, TRIB3, SESN2, NR4A1, SAA1, RPL23A, VEGFA, BoLA-DQB, PTHLH, H4, DDIT3, M-SAA3.2, and HIST1H2AC.

\section{Discussion}

In this study, we investigated the whole genome transcriptome profile of the bovine mammary epithelium in Holstein cows using RNA sequencing (RNA-seq), with the aim of identifying candidate genes for milk composition traits at a finer resolution. RNA-seq has many advantages over traditional cDNA microarray technologies: it is free from probe design issues or bias from hybridization issues [14] and easily detects low-abundance genes [15]. Marioni et al. reported that the Pearson correlation between RNA-Seq and qRT-PCR could reach 0.929, suggesting that the RNA-Seq technique is accurate and reproducible [15]. RNA-seq is the most powerful tool available for the deep research of the complexity of the transcriptome.

In our analysis, to minimize false-positive errors and ensure substantial detection power and accuracy, several strategies were applied to detect the differentially expressed genes between milking Holstein cows with high PP and FP and cows with low PP and FP, by controlling the critical influencing factors. We sequenced the transcripts deeply (5-10G of data per transcriptome), and performed the analysis using two commonly used package: DESeq and Cuffdiff. Only those differentially expressed genes ranked in the top half of the expressed genes were considered. By contrast, the differentially expressed genes expressed in the bottom half level were rooted out, as suggested by Rapaport et al. [30]. Of note, in our study design, only two biological replicates were used for each condition, because of the limited budget and sample availability. Rapaport et al. (2013) [30] investigated the impact of different sequencing depths and varying number of replicates on the identification of differentially expressed genes. They demonstrated that with most methods, over $90 \%$ of differently expressed genes at the top expression levels could be detected with using two replicates and 5\% of the reads [30]. However, more biological replications are still preferred and recommended to ensure broader application [30]. The more replicates are taken, the more the detection power is improved.

We identified 31 significantly differentially expressed genes whose mRNA levels changed between the Holstein cows with extremely high and low PP and FP, respectively 
Table 2 Summary of the GO analysis of 31 differentially expressed genes between the mammary gland of two cows with high milk protein and fat percentage and two cows with low protein and fat percentage

\begin{tabular}{|c|c|c|c|}
\hline GO ID & GO term & No. of differentially expressed genes & P-value \\
\hline GO:0034364 & High-density lipoprotein particle & 4 & $3.26 \mathrm{E}-06$ \\
\hline GO:0006953 & Acute-phase response & 4 & $3.26 \mathrm{E}-06$ \\
\hline GO:0001938 & Positive regulation of endothelial cell proliferation & 3 & $3.50 \mathrm{E}-05$ \\
\hline GO:0035767 & Endothelial cell chemotaxis & 2 & $5.11 \mathrm{E}-05$ \\
\hline GO:0043129 & Surfactant homeostasis & 3 & 0.000120 \\
\hline GO:0002042 & Cell migration involved in sprouting angiogenesis & 2 & 0.000126 \\
\hline GO:0035924 & Cellular response to vascular endothelial growth factor stimulus & 2 & 0.000224 \\
\hline GO:0007050 & Cell cycle arrest & 4 & 0.000321 \\
\hline GO:0043498 & Cell surface binding & 3 & 0.000347 \\
\hline GO:0030855 & Epithelial cell differentiation & 3 & 0.001532 \\
\hline GO:2000016 & Negative regulation of determination of dorsal identity & 1 & 0.001848 \\
\hline GO:0019912 & cyclin-dependent protein kinase activating kinase activity & 1 & 0.001848 \\
\hline GO:0001791 & IgM binding & 1 & 0.001848 \\
\hline GO:0002575 & Basophil chemotaxis & 1 & 0.001848 \\
\hline GO:0043184 & Vascular endothelial growth factor receptor 2 binding & 1 & 0.001848 \\
\hline GO:0005576 & Extracellular region & 9 & 0.002867 \\
\hline GO:0043433 & Negative regulation of sequence-specific DNA-binding transcription factor activity & 3 & 0.003109 \\
\hline GO:2000278 & Regulation of DNA biosynthetic process & 1 & 0.003694 \\
\hline GO:0070557 & PCNA-p21 complex & 1 & 0.003694 \\
\hline GO:0043183 & Vascular endothelial growth factor receptor 1 binding & 1 & 0.003694 \\
\hline GO:0002368 & B-cell cytokine production & 2 & 0.003694 \\
\hline GO:0030135 & Coated vesicle & 2 & 0.003694 \\
\hline GO:0048291 & Isotype switching to lgG isotypes & 2 & 0.003694 \\
\hline GO:0019862 & IgA binding & 1 & 0.003694 \\
\hline GO:0060649 & Mammary gland bud elongation & 2 & 0.003694 \\
\hline GO:0060659 & Nipple sheath formation & 2 & 0.003694 \\
\hline GO:0060319 & Primitive erythrocyte differentiation & 1 & 0.003694 \\
\hline GO:0042789 & mRNA transcription from RNA polymerase II promoter & 1 & 0.003694 \\
\hline GO:0010827 & Regulation of glucose transport & 1 & 0.003694 \\
\hline GO:0005172 & Vascular endothelial growth factor receptor binding & 1 & 0.003704 \\
\hline GO:0051451 & Myoblast migration & 1 & 0.003712 \\
\hline GO:0050731 & Positive regulation of peptidyl-tyrosine phosphorylation & 2 & 0.004336 \\
\hline GO:0002842 & Positive regulation of T-cell-mediated immune response to tumor cell & 2 & 0.005536 \\
\hline GO:0042026 & Protein refolding & 2 & 0.005536 \\
\hline GO:0033158 & Regulation of protein import into nucleus, translocation & 1 & 0.005537 \\
\hline GO:0055106 & Ubiquitin-protein ligase regulator activity & 1 & 0.005537 \\
\hline GO:0071603 & Endothelial cell-cell adhesion & 1 & 0.005554 \\
\hline GO:0015204 & Urea transmembrane transporter activity & 2 & 0.005573 \\
\hline GO:0071918 & Urea transmembrane transport & 2 & 0.005573 \\
\hline GO:0018401 & Peptidyl-proline hydroxylation to 4-hydroxy-L-proline & 1 & 0.005604 \\
\hline GO:0030141 & Stored secretory granule & 4 & 0.006394 \\
\hline GO:0002755 & MyD88-dependent toll-like receptor signaling pathway & 2 & 0.007375 \\
\hline GO:0015840 & Urea transport & 2 & 0.007376 \\
\hline
\end{tabular}


Table 2 Summary of the GO analysis of $\mathbf{3 1}$ differentially expressed genes between the mammary gland of two cows with high milk protein and fat percentage and two cows with low protein and fat percentage (Continued)

\begin{tabular}{llll}
\hline GO:0005372 & Water transmembrane transporter activity & 2 & 0.007376 \\
GO:0090050 & Positive regulation of cell migration involved in sprouting angiogenesis & 1 & 0.007379 \\
GO:0050927 & Positive regulation of positive chemotaxis & 1 & 0.007385 \\
GO:0060754 & Positive regulation of mast cell chemotaxis & 1 & 0.007434 \\
GO:0031077 & Post-embryonic camera-type eye development & 1 & 1 \\
GO:0043117 & Positive regulation of vascular permeability & 1 & 0.007435 \\
GO:0010740 & Positive regulation of intracellular protein kinase cascade & 2 & 0.007439 \\
GO:0008201 & Heparin binding & 1 & 0.007509 \\
GO:0007220 & Notch receptor processing & 3 & 0.007540 \\
GO:0005769 & Early endosome & 2 & 0.007634 \\
GO:0046696 & Lipopolysaccharide receptor complex & 1 & 0.008615 \\
GO:0043405 & Regulation of MAP kinase activity & 2 & 0.009213 \\
GO:0051428 & Peptide hormone receptor binding & Positive regulation of CREB transcription factor activity & 0.009217 \\
GO:0032793 & 0.009221 \\
\hline
\end{tabular}

$(p<0.05$, FDR $q<0.05)$. Among them, 14 genes were not only located within the known QTL regions for PP and FP, but were also close to significant SNPs for these traits detected by one or more independent previous GWASs [5,6,8,9], such as SAA3, HEATR7B2, TRIB3, SESN2, NR4A1, SAA1, RPL23A, VEGFA, BoLA-DQB, PTHLH, H4, DDIT3, $M-S A A 3.2$, and HIST1H2AC.

Tribbles homolog 3 (TRIB3), a pseudokinase, plays a critical role in the regulation of several signaling pathways involved in cell survival and/or cell stress, and inhibits phosphorylation of AKT/protein kinase B (AKT), which is an important enzyme in the signal transduction of growth factor receptors $[45,46]$. It is thought that TRIB3 can stimulate lipolysis by promoting ubiquitination and degradation of acetyl-coenzyme A carboxylase (ACC), which is a key regulatory enzyme in the fatty acid synthesis pathway in adipose tissue, through an association with the E3 ubiquitin ligase constitutive photomorphogenic protein 1 (COP1), an adaptor protein [47]. Hence, TRIB3 was suggested to negatively regulate fat synthesis. This evidence is consistent with the expression profile of TRIB3 gene in this study. As shown in Table 1, the mRNA level of TRIB3 in the cows with a low FP is higher than that in cows with a higher FP $(p<0.01, q<0.01)$. Our IPA pathway analysis also showed that TRIB3 gene was involved in lipid metabolism. More importantly, TRIB3 was near to the peak location of two reported QTLs for milk $\mathrm{PP}$ and FP and two significant SNPs for PP and FP $[5,8]$. Taken together, the analyses indicate that TRIB3 is one of the most promising candidate genes for milk FP in dairy cattle.

Table 3 Gene function and pathway analysis of 31 differentially expressed genes between the mammary gland of two cows with high milk protein and fat percentage and two cows with low protein and fat percentage with IPA

\begin{tabular}{|c|c|c|c|}
\hline Pathway & Functional annotation & p-value & Gene \\
\hline Lipid metabolism & Export of cholesterol & $3.36 \mathrm{e}-04$ & SAA1 \\
\hline \multirow[t]{3}{*}{ Lipid metabolism } & Accumulation of beta-estradiol & $6.73 e-04$ & SAA1 \\
\hline & Concentration of bile acid & & \\
\hline & Apoptosis of epithelial cell lines & & \\
\hline \multirow[t]{3}{*}{ Lipid metabolism } & Cell death of connective tissue cells & $6.38 \mathrm{e}-03$ & ATF3 \\
\hline & Cell death of epithelial cells & & \\
\hline & development of endothelial cell lines & & \\
\hline Lipid metabolism & Quantity of steroid & $8.53 e-03$ & ATF3, SAA1 \\
\hline Lipid metabolism & Fatty acid metabolism & $1.25 \mathrm{e}-02$ & TRIB3, SAA1 \\
\hline Lipid metabolism & Efflux of cholesterol & $2.27 e-02$ & SAA1 \\
\hline Lipid metabolism & Homeostasis of cholesterol & $2.37 e-02$ & SAA1 \\
\hline Lipid metabolism & Metabolism of cholesterol & $3.16 \mathrm{e}-02$ & SAA1 \\
\hline
\end{tabular}


Table 4 Detailed information on the reported QTLs containing the 31 differentially expressed genes between the mammary gland of two cows with high milk protein and fat percentage and two cows with low protein and fat percentage

\begin{tabular}{|c|c|c|c|c|c|c|}
\hline \multirow{2}{*}{$\begin{array}{l}\text { Gene } \\
\text { name }\end{array}$} & \multirow[t]{2}{*}{ Position (bp) } & \multirow{2}{*}{$\begin{array}{l}\text { Position } \\
\text { (cM) }\end{array}$} & \multicolumn{4}{|c|}{ Previously reported QTL } \\
\hline & & & $\begin{array}{l}\text { Distance to QTL } \\
\text { peak (cM) }\end{array}$ & $\begin{array}{c}\mathrm{Cl} \text { and peak } \\
\text { location (cM) }\end{array}$ & Trait & References \\
\hline$\overline{S A A 3}$ & $26668046-26671801$ & Chr29: 36.8 & 12.6 & Peak: 24.2 & PP & Bagnato et al., J Dairy Sci, 2008 [33] \\
\hline \multirow[t]{4}{*}{ HEATR7B2 } & $33456348-33528569$ & Chr20: 37.5 & 5.6 & 20.2-43.5 (peak: 31.9) & $F P, P P$ & Arranz et al., Anim Genet, 1998 [34] \\
\hline & & & 6.3 & 37.8-49.7 (peak: 43.8) & PP & Ashwell et al., J Dairy Sci, 2004 [35] \\
\hline & & & 0.2 & Peak: 37.7 & $F P, P P$ & Zhang et al., Genetics, 1998 [36] \\
\hline & & & 5.2 & 15.5-68.0 (peak: 42.7) & PP & Bennewitz et al., Genetics, 2004 [37] \\
\hline \multirow[t]{2}{*}{ TRIB3 } & $61176217-61187210$ & Chr13: 75.8 & 5.2 & Peak: 81.0 & PP & Bagnato et al., J Dairy Sci, 2008 [33] \\
\hline & & & 5.0 & Peak: 80.8 & $F P, P P$ & Pimentel et al., Anim Genet, 2011 [38] \\
\hline SESN2 & $125698159-125714128$ & Chr2: 116.2 & 14.6 & Peak: 101.6 & $F P, P P$ & Pimentel et al., Anim Genet, 2011 [38] \\
\hline HSPD1 & $86438978-86449372$ & Chr2: 81.0 & 6.5 & Peak: 74.5 & $\mathrm{PP}$ & Bagnato et al., J Dairy Sci, 2008 [33] \\
\hline NR4A1 & $27977006-27992869$ & Chr5: 32.5 & 12.1 & 29.4-45.5 (peak: 44.6) & PP & Bennewitz et al., Genet Sel Evol, 2003 [39] \\
\hline SAA1 & $26693328-26696498$ & Chr29: 35.8 & 11.6 & Peak: 24.2 & PP & Bagnato et al., J Dairy Sci, 2008 [33] \\
\hline \multirow[t]{2}{*}{$R P L 23 A$} & $21526905-21574655$ & Chr11:27.8 & 5.8 & Peak: 33.6 & $\mathrm{FP}$ & Ashwell et al., J Dairy Sci, 1998 [40] \\
\hline & & & 8.4 & Peak: 19.4 & PP & Bagnato et al., J Dairy Sci, 2008 [33] \\
\hline \multirow[t]{2}{*}{ VEGFA } & $17255946-17269998$ & Chr23: 25.8 & 2.5 & 20.7-41.9 (peak: 28.3) & $\mathrm{PP}$ & Viitala et al., J Dairy Sci, 2003 [41] \\
\hline & & & 2.5 & 14.8-42.9 (peak: 28.3) & $\mathrm{PP}$ & Elo et al., Mamm Genome, 1999 [42] \\
\hline \multirow[t]{4}{*}{ KRT24 } & $41557544-41561796$ & Chr19: 66.1 & 4.1 & Peak: 70.2. & PP & Bagnato et al., J Dairy Sci, 2008 [33] \\
\hline & & & 2.2 & Peak: 63.9 & PP & Mosig et al., Genetics, 2001 [43] \\
\hline & & & 4.0 & Peak: 62.1 & PP & Bennewitz et al., Genetics, 2004 [37] \\
\hline & & & 0.8 & 64.5-69.8 (peak: 66.9) & $\mathrm{FP}$ & Bennewitz et al., Genet Sel Evol, 2003 [39] \\
\hline CDKN1A & $10560498-10568780$ & Chr23: 16.1 & 12.4 & 14.8-42.9 (peak: 28.5) & PP & Elo et al., Mamm Genome, 1999 [42] \\
\hline \multirow[t]{3}{*}{$B O L A-D Q B$} & $25375269-25388620$ & Chr23: 38.2 & 9.9 & 14.8-42.9 (peak: 28.3) & PP & Elo et al., Mamm Genome, 1999 [42] \\
\hline & & & 9.9 & 20.7-41.9 (peak: 28.3) & PP & Viitala et al., J Dairy Sci, 2003 [41] \\
\hline & & & 4.7 & Peak: 42.9 & PP & Bagnato et al., J Dairy Sci, 2008 [33] \\
\hline \multirow[t]{4}{*}{ PTHLH } & $82246521-82258858$ & Chr5: 90.7 & & $76.2-103.1$ & $\mathrm{PP}$ & Schrooten et al., J Dairy Sci, 2004 [44] \\
\hline & & & 1.1 & 5.3-104.9 (peak: 89.6) & $\mathrm{FP}$ & Bennewitz et al., Genetics, 2004 [37] \\
\hline & & & 11.6 & 34.1-108.3 (peak: 102.3) & PP & Bennewitz et al., Genetics, 2004 [37] \\
\hline & & & 5.2 & 80.1-90.8 (peak: 85.5) & $\mathrm{FP}$ & Ashwell et al., J Dairy Sci, 2004 [35] \\
\hline $\mathrm{H} 4$ & $31665561-31667068$ & Chr23: 46.8 & 3.9 & Peak: 42.9 & $\mathrm{PP}$ & Bagnato et al., J Dairy Sci, 2008 [33] \\
\hline \multirow[t]{2}{*}{ DDIT3 } & $56285007-56307931$ & Chr5: 61.2 & 28.4 & 6.9-102.6 (peak: 89.6) & $\mathrm{FP}$ & Bennewitz et al., Genetics, 2004 [37] \\
\hline & & & & $32.3-69.7$ & $\mathrm{PP}$ & Schrooten et al., J Dairy Sci, 2004 [44] \\
\hline M-SAA3.2 & $26755567-26759547$ & Chr29: 37.8 & 13.6 & Peak: 24.2 & PP & Bagnato et al., J Dairy Sci, 2008 [33] \\
\hline HIST1H2AC & $31579046-31589230$ & Chr23: 46.7 & 3.8 & Peak: 42.9 & $\mathrm{PP}$ & Bagnato et al., J Dairy Sci, 2008 [33] \\
\hline
\end{tabular}

${ }^{1}$ The linkage position was estimated relative to UMD3.1.66 and based on the QTL mapper v.2.019 at www.animalgenome.org/cgi-bin/QTLdb/.

PP: protein percentage; FP: fat percentage.

Vascular endothelial growth factor A (VEGFA) is a heparin-binding growth factor specific for vascular endothelial cells, with a potent angiogenic capacity, both in physiological and pathological conditions [48]. VEGF has an essential regulatory role in the secretory and immunological functions of the mammary gland, such as angiogenesis, vascular permeability, and migration of mononuclear leukocytes [48]. Alkafafy (2005) found that
VEGF-immunoreactive mast cells release a variety of angiogenic factors in the bovine mammary gland epididymal interstitium [49]. TR3/NR4A1, also a differentially expressed gene in this study, is the transcription factor that regulates VEGFA-mediated angiogenesis [50]. Integrated analysis revealed that VEGFA was near to the peak positions of two QTLs for PP, and very close to significant SNPs for PP and FP detected in two previous 
Table 5 Detailed information on the nearest and most significant SNPs from previous GWAS to the 31 differentially expressed genes between the mammary gland of two cows with high milk protein and fat percentage and two cows with low protein and fat percentage

\begin{tabular}{|c|c|c|c|c|c|c|c|}
\hline \multirow{2}{*}{$\begin{array}{l}\text { Gene } \\
\text { name }\end{array}$} & \multirow[t]{2}{*}{ Gene position $(b p)^{1}$} & \multicolumn{3}{|c|}{ Nearest and most significant SNPs of GWAS } & \multirow[t]{2}{*}{ Traits } & \multirow[t]{2}{*}{ Raw $p$ value } & \multirow[t]{2}{*}{ Reference } \\
\hline & & Distance & Name & $\begin{array}{l}\text { Position } \\
\text { (bp) }^{2}\end{array}$ & & & \\
\hline \multirow[t]{2}{*}{$\overline{S A A 3}$} & \multirow[t]{2}{*}{ Chr29: 26668046-26671801 } & $49.5 \mathrm{~Kb}$ & ARS-BFGL-NGS-24998 & 26721324 & PP & $2.96 \mathrm{E}-08$ & \multirow{2}{*}{$\begin{array}{c}\text { Cole et al., BMC Genomics, } \\
2011[8]\end{array}$} \\
\hline & & $4.2 \mathrm{Mb}$ & UA-IFASA-8605 & 30901735 & $F P, P P$ & $\begin{array}{l}4.90 \mathrm{E}-13 \\
1.50 \mathrm{E}-16\end{array}$ & \\
\hline \multirow[t]{2}{*}{ HEATR7B2 } & \multirow[t]{2}{*}{ Chr20: $33455667-33528569$} & $23.2 \mathrm{~Kb}$ & ARS-BFGL-BAC-2469 & 33433160 & PP & $1.21 \mathrm{E}-08$ & Jiang et al., Plos One, 2010 [6] \\
\hline & & $2.6 \mathrm{Mb}$ & rs41640170 & 36097136 & PP & $1 \mathrm{E}-6.88$ & $\begin{array}{l}\text { Schopen et al., J Dairy Sci, } \\
2011 \text { [9] }\end{array}$ \\
\hline \multirow[t]{2}{*}{ TRIB3 } & \multirow[t]{2}{*}{ Chr13: 61176217-61187210 } & $2.1 \mathrm{Mb}$ & BFGL-NGS-119420 & 59101909 & $F P, P P$ & $\begin{array}{l}1.14 \mathrm{E}-21 \\
3.49 \mathrm{E}-18\end{array}$ & $\begin{array}{c}\text { Cole et al., BMC Genomics, } \\
2011[8]\end{array}$ \\
\hline & & $9.3 \mathrm{Mb}$ & rs29021058 & 70524323 & PP & 0.0018 & $\begin{array}{c}\text { Kolbehdari et al., J Anim Breed } \\
\text { Genet, } 2009 \text { [5] }\end{array}$ \\
\hline \multirow[t]{2}{*}{ SESN2 } & \multirow[t]{2}{*}{ Chr2: 125698159-125714128 } & $2.0 \mathrm{Mb}$ & ARS-BFGL-NGS-69013 & 123717269 & $F P, P P$ & $\begin{array}{l}1.46 \mathrm{E}-11 \\
3.26 \mathrm{E}-09\end{array}$ & \multirow[t]{2}{*}{$\begin{array}{c}\text { Cole et al., BMC Genomics, } \\
2011[8]\end{array}$} \\
\hline & & $2.7 \mathrm{Mb}$ & BTA-31250-no-rs & 128437731 & $F P, P P$ & $\begin{array}{l}3.75 \mathrm{E}-10 \\
1.26 \mathrm{E}-24\end{array}$ & \\
\hline CHACl & Chr10: 36598393-36600764 & $0.16 \mathrm{Mb}$ & Hapmap53714-rs29017586 & 36758715 & $F P, P P$ & $\begin{array}{l}9.84 \mathrm{E}-07 \\
6.64 \mathrm{E}-12\end{array}$ & $\begin{array}{c}\text { Cole et al., BMC Genomics, } \\
2011[8]\end{array}$ \\
\hline$N R 4 A 1$ & Chr5: 27977006-27992869 & $0.99 \mathrm{Mb}$ & ARS-BFGL-NGS-5790 & 26986116 & $F P, P P$ & $\begin{array}{l}3.26 \mathrm{E}-14 \\
9.43 \mathrm{E}-28\end{array}$ & $\begin{array}{c}\text { Cole et al., BMC Genomics, } \\
2011[8]\end{array}$ \\
\hline \multirow[t]{2}{*}{ SAA1 } & \multirow[t]{2}{*}{ Chr29: 26693328-26696498 } & $24.8 \mathrm{~Kb}$ & ARS-BFGL-NGS-24998 & 26721324 & PP & $2.96 \mathrm{E}-08$ & \multirow{2}{*}{$\begin{array}{l}\text { Cole et al., BMC Genomics, } \\
2011[8]\end{array}$} \\
\hline & & $4.2 \mathrm{Mb}$ & UA-IFASA-8605 & 30901735 & $F P, P P$ & $\begin{array}{l}4.90 \mathrm{E}-13 \\
1.50 \mathrm{E}-16\end{array}$ & \\
\hline \multirow[t]{2}{*}{ ATF3 } & \multirow[t]{2}{*}{ Chr16: $72820025-72832974$} & $1.9 \mathrm{Mb}$ & ARS-BFGL-NGS-70836 & 74741746 & PP & $3.58 \mathrm{E}-07$ & \multirow{2}{*}{$\begin{array}{c}\text { Cole et al., BMC Genomics, } \\
2011[8]\end{array}$} \\
\hline & & $3.3 \mathrm{Mb}$ & ARS-BFGL-NGS-85980 & 76091078 & $F P, P P$ & $\begin{array}{l}\text { 6.46E-07, } \\
8.33 \mathrm{E}-09\end{array}$ & \\
\hline \multirow[t]{2}{*}{$R P L 23 A$} & \multirow[t]{2}{*}{ Chr11: 21526905-21574655 } & $0.5 \mathrm{Mb}$ & ARS-BFGL-NGS-100459 & 22128569 & PP & $1.03 E-24$ & \multirow{2}{*}{$\begin{array}{l}\text { Cole et al., BMC Genomics, } \\
2011 \text { [8] }\end{array}$} \\
\hline & & $4.0 \mathrm{Mb}$ & BTB-01766447 & 17484533 & $F P, P P$ & $\begin{array}{l}4.51 \mathrm{E}-18 \\
8.90 \mathrm{E}-11\end{array}$ & \\
\hline $\mathrm{CDH} 16$ & Chr18: 34733117-34743031 & $0.75 \mathrm{Mb}$ & ARS-BFGL-NGS-107749 & 33986486 & $F P, P P$ & $\begin{array}{l}2.54 \mathrm{E}-13 \\
3.55 \mathrm{E}-18\end{array}$ & $\begin{array}{c}\text { Cole et al., BMC Genomics, } \\
2011[8]\end{array}$ \\
\hline \multirow[t]{3}{*}{ VEGFA } & \multirow[t]{3}{*}{ Chr23: 17255946-17269998 } & $2.9 \mathrm{Mb}$ & ARS-BFGL-NGS-29490 & 20166517 & $F P, P P$ & $\begin{array}{l}4.05 E-20 \\
2.32 E-26\end{array}$ & $\begin{array}{c}\text { Cole et al., BMC Genomics, } \\
2011[8]\end{array}$ \\
\hline & & $1.8 \mathrm{Mb}$ & rs29016156 & 15422973 & PP & 0.00099 & $\begin{array}{l}\text { Kolbehdari et al., J Anim Breed } \\
\text { Genet, } 2009 \text { [5] }\end{array}$ \\
\hline & & $0.19 \mathrm{Mb}$ & rs41640789 & 17061460 & $\mathrm{FP}$ & 0.00012 & $\begin{array}{c}\text { Kolbehdari et al., J Anim Breed } \\
\text { Genet, } 2009 \text { [5] }\end{array}$ \\
\hline$B O L A-D Q B$ & Chr23: 25375269-25388620 & $4.9 \mathrm{Mb}$ & ARS-BFGL-NGS-72191 & 30279220 & $F P, P P$ & $\begin{array}{l}8.46 \mathrm{E}-17 \\
1.09 \mathrm{E}-28\end{array}$ & $\begin{array}{c}\text { Cole et al., BMC Genomics, } \\
2011[8]\end{array}$ \\
\hline$A R I D 1 B$ & Chr9: 94882343-95271883 & $0.37 \mathrm{Mb}$ & ARS-BFGL-NGS-81082 & 94511747 & $F P, P P$ & $\begin{array}{l}3.00 \mathrm{E}-11 \\
2.37 \mathrm{E}-08\end{array}$ & $\begin{array}{c}\text { Cole et al., BMC Genomics, } \\
2011[8]\end{array}$ \\
\hline \multirow[t]{4}{*}{ PTHLH } & \multirow[t]{4}{*}{ Chr5: $82246521-82258858$} & $1.5 \mathrm{Mb}$ & Hapmap51303-BTA-74377 & 83790390 & $\mathrm{FP}$ & $1.20 \mathrm{E}-06$ & Jiang et al., Plos One, 2010 [6] \\
\hline & & $0.63 \mathrm{Mb}$ & ARS-BFGL-NGS-29557 & 81612132 & $F P, P P$ & $\begin{array}{l}2.97 \mathrm{E}-13 \\
5.97 \mathrm{E}-25\end{array}$ & $\begin{array}{l}\text { Cole et al., BMC Genomics, } \\
2011[8]\end{array}$ \\
\hline & & $6.2 \mathrm{Mb}$ & rs41590827 & 76049666 & PP & 0.00013 & $\begin{array}{c}\text { Kolbehdari et al., J Anim Breed } \\
\text { Genet, } 2009 \text { [5] }\end{array}$ \\
\hline & & $9.9 \mathrm{Mb}$ & rs41569048 & 92162494 & PP & $1 \mathrm{E}-4.72$ & $\begin{array}{l}\text { Schopen et al., J Dairy Sci, } \\
2011 \text { [9] }\end{array}$ \\
\hline H4 & Chr23: 31665561-31667068 & $1.4 \mathrm{Mb}$ & ARS-BFGL-NGS-72191 & 30279220 & $F P, P P$ & $\begin{array}{l}8.46 \mathrm{E}-17 \\
1.09 \mathrm{E}-28\end{array}$ & $\begin{array}{c}\text { Cole et al., BMC Genomics, } \\
2011[8]\end{array}$ \\
\hline
\end{tabular}


Table 5 Detailed information on the nearest and most significant SNPs from previous GWAS to the 31 differentially expressed genes between the mammary gland of two cows with high milk protein and fat percentage and two cows with low protein and fat percentage (Continued)

\begin{tabular}{|c|c|c|c|c|c|c|c|}
\hline FAM71A & Chr16: 72811910-72814133 & $2.5 \mathrm{Mb}$ & ARS-BFGL-NGS-85980 & 76091078 & $F P, P P$ & $\begin{array}{l}\text { 6.46E-07, } \\
8.33 \mathrm{E}-09\end{array}$ & $\begin{array}{l}\text { Cole et al., BMC Genomics, } \\
2011 \text { [8] }\end{array}$ \\
\hline THBS4 & Chr10: 10945424-10999244 & $0.90 \mathrm{Mb}$ & BTB-00411816 & 11899342 & $F P, P P$ & $\begin{array}{l}2.71 E-14 \\
3.45 E-25\end{array}$ & $\begin{array}{l}\text { Cole et al., BMC Genomics, } \\
\qquad 2011[8]\end{array}$ \\
\hline DDIT3 & Chr5: 56285007-56307931 & $0.46 \mathrm{Mb}$ & ARS-BFGL-NGS-14781 & 56766165 & FP & 5.54E-10 & $\begin{array}{c}\text { Cole et al., BMC Genomics, } \\
2011[8]\end{array}$ \\
\hline \multirow[t]{2}{*}{ M-SAA3.2 } & \multirow[t]{2}{*}{ Chr29: 26755567-26759547 } & $34.2 \mathrm{~Kb}$ & ARS-BFGL-NGS-24998 & 26721324 & PP & $2.96 \mathrm{E}-08$ & \multirow{2}{*}{$\begin{array}{c}\text { Cole et al., BMC Genomics, } \\
2011[8]\end{array}$} \\
\hline & & $4.1 \mathrm{Mb}$ & UA-IFASA-8605 & 30901735 & $F P, P P$ & $\begin{array}{l}\text { 7.90E-13, } \\
1.50 \mathrm{E}-16\end{array}$ & \\
\hline HIST1H2AC & Chr23: 31579046-31589230 & $0.95 \mathrm{Mb}$ & BTA-68781-no-rs & 30711619 & $F P, P P$ & $\begin{array}{l}1.17 \mathrm{E}-17 \\
6.08 \mathrm{E}-27\end{array}$ & $\begin{array}{c}\text { Cole et al., BMC Genomics, } \\
2011[8]\end{array}$ \\
\hline P4HA2 & Chr7: 23480314-23513315 & $1.1 \mathrm{Mb}$ & Hapmap49309-BTA-78604 & 24655689 & PP & 4.34E-14 & $\begin{array}{c}\text { Cole et al., BMC Genomics, } \\
2011[8]\end{array}$ \\
\hline
\end{tabular}

1,2 Means the position on the bovine genome sequence of UMD3.1.66.

PP: protein percentage; FP: fat percentage.

GWAS reports $[5,8]$, one of which was ranked in the top 100 most significant SNPs by Cole et al. [8]. Thus, VGEFA may be a promising candidate gene for milk PP and FP.

Parathyroid hormone-like hormone (PTHLH), also known as parathyroid hormone-related protein (PTHrP), was first identified as a parathyroid hormone (PTH)-like factor responsible for humoral hypercalcemia in malignancies [51]. Similar evidence indicated that bovine mammary PTHLH is closely related to the Ca concentration in milk [52]. PTHLH is expressed in the mammary gland and appears to be critical for the morphogenesis and angiogenesis of this structure, and its production in the mammary gland is generally attributed to epithelial cells [53]. Reduction of PTHLH's expression to very low levels prevented mammary gland development, and genetic disruption of this gene results in a failure of mammary development in mice and humans [54]. Similar to TRIB3 and VEGFA genes, PTHLH is not only close to the PP and FP of QTLs but also is near to significant SNPs that were detected by four independent GWASs $[5,6,8,9]$. Therefore, PTHLH also represents a candidate gene for milk PP and FP. A previous study showed a similar result: PTHLH was differentially expressed between before parturition and in early lactation in Holstein dairy cows [22].

$S A A$ is a multigene family comprising four genes $(S A A 1-4)$ that may play a direct physiological role in local and systemic inflammation, and free fatty acid production and cholesterol metabolism. SAA is an apolipoprotein and a component of high-density lipoprotein (HDL) particles [55]. Serum amyloid A3 (SAA3) participates in lipid metabolism, cholesterol transport, and apoptosis of mammary epithelial cells [56-58]. Several previous studies showed that the mRNA level of $S A A 3$ changed across the different periods of mammary gland development and lactation in cows, horses, sheep, and goats $[59,60]$. Bovine $M-S A A 3$ was differentially expressed by the mammary epithelium in response to PRL, which regulates a wide spectrum of physiological processes, such as mammary gland development, lactation, and immune function; thus, $M-S A A 3$ has an important tissue-specific function during lactation and mammary infection [61]. Furthermore, SAA1, SAA3, and $M-S A A 3$ are located within the QTL region for $\mathrm{PP}$ and near to a significant SNP for PP and FP (Tables 4 and 5). SAA1 was also shown to be involved in lipid metabolism by IPA pathway analysis.

There are only a few reports regarding ribosomal protein L23A (RPL23A), histone H4 (H4), and histone cluster 1, H2ac (HIST1H2AC). RPL23A plays a very important role in translation and participates in extra-ribosomal functions, such as apoptosis, cell division, and differentiation [62-64]. Histone $\mathrm{H} 4$ is one of four core histones $(\mathrm{H} 2 \mathrm{~A}, \mathrm{H} 2 \mathrm{~B}, \mathrm{H} 3$, and $\mathrm{H} 4)$, which are basic nuclear proteins and are responsible for the nucleosome structure of the chromosomal fiber in eukaryotes. HIST1H2AC is located in the large histone gene cluster on BTA23. Although the two genes were close to a QTL for milk PP and near to the most significant SNPs for milk PP and FP [8], to date, little is known as to whether the two genes are associated with quantitative traits such as milk production traits. Histone acetylation is an important epigenetic modification. Modifications of lysine residues of core histones have the greatest potential for unfolding chromatin to recruit different transcriptional factors, which is almost invariably associated with activation of gene transcription [65]. Our data implied that epigenetic regulation might be involved in milk production and mammary gland development through histone modifications. 
In addition, integrated analysis of differential expression patterns, QTL and GWAS evidence, and biological functions revealed that five other genes, namely $S E S N 2$, NR4A1, DDIT3, HEATR7B2, and BoLA-DQB, were also associated with milk composition traits to some extent. These five genes are located near the peak positions of known QTLs and several significant SNPs for milk PP and FP (Tables 4 and 5). Sestrin 2 (SESN2) is involved in DNA damage and genetic instability [66]. Deficiency of SESN2 in some cell lines resulted in growth inhibition instead of growth stimulation [67]. NR4A1 belongs to the NR4A family of nuclear receptors, and is considered a mediator/regulator of cell survival and apoptosis in breast cancer cells; it is up-regulated in primary breast cancer compared with normal tissue [68]. NR4A receptors act as transcription factors, altering the expression of downstream genes, e.g. VEGF, in angiogenesis, proliferation, DNA repair, metabolism, and cell migration [69]. DNA-damage-inducible transcript 3 protein (DDIT3) is a member of the leucine zipper transcription factor family, which is implicated in adipocyte differentiation [70]. ATF3 belongs to the mammalian activation transcription factor/ cAMP responsive element-binding (CREB) protein family of transcription factors. It is generally viewed as a transcriptional repressor and represses the transcription of DDIT3 [71,72]. GO and IPA analysis indicated that both DDIT3 and ATF3 are involved in accumulation of glycoproteins, apoptosis, and regeneration of epithelial cells. There is no information available for HEATR7B2 (maestro heat-like repeat family member $2 B$ ). BoLA-DQB is one of the major histocompatibility complex (MHC) class II molecules that play a central role in the regulation of the immune response. Generally, it is thought that $M H C$ genes affect production traits indirectly by increasing the overall disease resistance of the individual. Bionaz et al. also found that the expression of $M H C$ class I molecules decreased from the beginning of lactation to 120 days compared with 230 days in cows [23]. The mammary gland is actively involved in the immune system and is an evolutionary product of the innate immune system. The MHC pathway is a vesicle-dependent process, which uses ERGolgi networks, as do milk components; thus, the MHC can be considered a competitor of the vesicle-transport system, which may explain its deceased activity implied herein [23].

Previous studies on bovine milk and mammary transcriptomes over various lactation periods revealed several metabolic pathways related to bovine mammary and lactation, such as energy synthesis, lipid metabolism, protein synthesis, cell cycle/death, angiogenesis, immune function, and epigenetic regulation [18,20-23]. Our results were consistent with these reports (Tables 1, 2 and 3).

The interpretation of the findings from the present study still has limitations. In cow's milk, there are two major protein groups: caseins ( $\alpha \mathrm{S} 1$-casein, $\alpha \mathrm{S} 2$-casein, $\beta$-casein, and $\kappa$-casein) and whey proteins ( $\alpha$-lactalbumin and lactoglobulin). However, our study did not show significant changes in milk protein mRNA expression. Similar results were observed by previous investigations, which showed that none of the milk protein genes (caseins, $\alpha$-lactalbumin, and $\beta$-lactoglobulin) showed significant changes in expression from late pregnancy to early lactation [22], and in the lactating mammary gland compared with the non-lactating mammary gland [73] in Holstein dairy cows. Such a phenomenon may be explained if the expression of milk protein genes reaches a plateau in late lactation [22]. DGAT1 and Jak-STAT genes, with large effect on milk traits, were not differentially expressed between the high and low groups in this study. Such a result is similar to those reported by Finucane et al. [22] and Buinaz et al. [23]. In addition, our RNA-seq data indicated that 28 of the 31 differentially expressed genes were downregulated in the cows with higher PP and FP compared with the low group. Although it is reasonable to expect that lactation requires increased expression or turning-on of many genes, the same result was observed in a previous bovine mammary transcriptome analysis, which found that more than twice as many genes were downregulated than upregulated in early lactation compared with non-lactation (before parturition) in Holstein dairy cows [22].

Currently, genomic selection is the main application used in animal breeding in dairy cattle, in which the Illumina $50 \mathrm{~K}$ chip and GeneSeek $90 \mathrm{~K}$ chip are commonly used. Most of the SNP markers in these two types of chips were collected from the current SNP database and are almost evenly distributed across the whole genome. Thus, certain major genes with large genetic effects on one or milk milk traits could be put into the SNP chip instead of used in marker/gene-assisted selection to increase selection efficiency in some specific dairy cattle populations.

\section{Conclusions}

The present study provided a global view of the complexity of the bovine mammary epithelium cell transcriptome, and revealed 31 differentially expressed genes between Holstein cows with extremely high and low milk PP and FP. Integrated analysis of differential gene expression, QTL and GWAS data, and biological functions suggested that seven genes, including TRIB3, SAA (SAA1, SAA3, and M-SAA3.2), VEGFA, PTHLH, and RPL23A, represent the most promising candidates affecting milk PP and FP of dairy cattle.

\section{Additional files}

Additional file 1: Figure S1. Genotypes of DGAT1 p.Lys232Ala mutation for four cows detected by PCR product sequencing. Arrowhead indicates the two nucleotides of DGAT1 p.Lys232Ala mutation. 
Additional file 2: Table S1. The basic statistics for RNA-seq reads generated from mammary glands of two cows with high milk protein and fat percentage and two cows with low protein and fat percentage, and the subsequent alignment information with Tophat!

Additional file 3: Table S2. PCR primers for qRT-PCR validation of 11 differentially expressed genes between the mammary gland of two cows with high milk protein and fat percentage and two cows with low protein and fat percentage.

Additional file 4: Figure S2. Correlation between biological replicates within two cows with high milk PP and FP and two cows with low PP and FP. The $x$ - and $y$-axis correspond to the FPKM value of each sample. High and low in the $x$ - and $y$-axis mean two cows with high milk PP and FP and two cows with low PP and FP, respectively. The correlation coefficient $\left(R^{2}\right)$ between two individuals within each group was calculated based on FPKM value of each individual. $R^{2}$ was used to evaluate the read similarity and reliability of biological replicates within group.

Additional file 5: Figure S3. Comparison of the expression ratios of 11 randomly chosen differentially expressed genes between the mammary glands of two cows with high milk PP and FP and two cows with low PP and FP using RNA-seq and GRT-PCR. A. Black and gray columns represent the relative mRNA expression levels by qRT-PCR normalized by GAPDH and $A C T B$, respectively; white columns show the $\log _{10}$ (fragments per kilobase of transcript per million fragments mapped; FPKM) value obtained by RNA-seq. High and low in the $x$-axis mean cows with high and low PP and FP, respectively. B-1. The $x$ - and $y$-axis show the log2 (ratio of mRNA levels, low/high) measured by qRT-PCR (normalized by $G A P D H$ and RNA-seq, respectively. B-2. The $x$ - and $y$-axis shows the log2 (ratio of mRNA levels, low/high) measured by qRT-PCR (normalized by $A C T B)$ and RNA-seq, respectively.

\section{Abbreviations}

QTL: Quantitative trait locus; LA: Linkage analysis; LD: Linkage disequilibrium; GWAS: Genome-wide association study; DGAT1: AcylCoA: diacylglycerol acyltransferase; GHR: Growth hormone receptor; NGS: Next generation sequencing; RNA-seq: RNA-sequencing; MY: Milk yield; FY: Fat yield; PY: Protein yield; FP: Fat percentage; PP: Protein percentage; DHI: Dairy herd improvement; DAC: Dairy association of China; RIN: RNA integrity number; FRKM: Fragments per kilobase of transcript per million mapped fragments; GO: Gene ontology; IPA: Ingenuity pathways analysis; qRT-RCP: Real-time quantitative reverse-transcription polymerase chain reaction; TRIB3: Tribbles homolog 3; PTHLH: Parathyroid hormone-like hormone; ARID1B: AT rich interactive domain 1B (SWI1-like); ZC3H14: Zinc finger CCCH-type containing 14; H4: Histone H4; DDIT3: DNA-damage-inducible transcript 3; CHAC1: Cation transport regulator homolog 1; SAA3: Serum amyloid A3; ATF3: Activating transcription factor 3; HEATR7B2: HEAT repeat family member 7B2; SESN2: Sestrin 2; NR4A1: Nuclear receptor subfamily 4, group A, member 1; SAA1: Serum amyloid A1; RPL23A: Ribosomal protein L23a; VEGFA: Vascular endothelial growth factor A; THBS4: Thrombospondin 4; CSN3: K-casein; CSN2: $\beta$-casein; LALBA: a-lactalbumin; MBLG: $\beta$-lactoglobulin; STAT5A: Signal transducer and activator of transcription5A; STAT5B: Signal transducer and activator of transcription5B; SCD: Stearoyl-coenzyme A desaturase; KRT24: Keratin 24; EIF4G3: Eukaryotic translation initiation factor 4 gamma, 3; CDKN1A: Cyclin-dependent kinase inhibitor 1A; GAD2: Glutamate decarboxylase 2; FDR: False discovery rate; ACC: Acetyl-coenzyme A carboxylase; COP1: Constitutive photomorphogenic protein 1; PTHrP: Parathyroid hormone-related protein; H: Histone; CREB: CAMP responsive element-binding; BTA: Bos Taurus autosome; SNP: Single nucleotide polymorphism.

\section{Competing interests}

The authors declare that they have no competing interests.

\section{Authors' contributions}

XC performed the RNA-related experiments, data analysis, and prepared the manuscript. YH contributed to the bioinformatics analysis of the sequencing data. SY and YX collected the samples and performed the RNA experiments. $\mathrm{SZ}, \mathrm{QZ}$, and YZ participated in the experimental design, result interpretation, and sample collection. XL participated in the data analysis. GEL performed the gene function and pathway analysis. DS conceived and designed the experiments, and prepared the manuscript. All authors read and approved the final manuscript.

\section{Acknowledgments}

This work was supported by the National Science and Technology Programs of China (2013AA102504, 2011BAD28B02, 2012BAD12B01, 2014ZX08009-053B), the Beijing Innovation Team of Technology System in the National Dairy Industry, the Beijing Research and Technology Program (D121100003312001), and the Program for Changjiang Scholar and Innovation Research Team in University (IRT1191). The authors would also like to thank the Dairy Data Center of China for providing pedigree information and DHI data for Chinese Holstein cows.

\section{Author details}

'Key Laboratory of Animal Genetics and Breeding of Ministry of Agriculture, National Engineering Laboratory of Animal Breeding, College of Animal Science and Technology, China Agricultural University, Beijing 100193, China. ${ }^{2}$ Laboratory of Disease Genomics and Individualized Medicine, Beijing Institute of Genomics, Chinese Academy of Sciences, Beijing 100029, China. ${ }^{3}$ Bovine Functional Genomics Laboratory, ANRI, USDA-ARS, Beltsville, MD 20705, USA

Received: 6 February 2013 Accepted: 18 March 2014

Published: 24 March 2014

\section{References}

1. Georges M, Nielsen D, Mackinnon M, Mishra A, Okimoto R, Pasquino AT, Sargeant LS, Sorensen A, Steele MR, Zhao X: Mapping quantitative trait loci controlling milk production in dairy cattle by exploiting progeny testing. Genetics 1995, 139:907-920.

2. Daetwyler HD, Schenkel FS, Sargolzaei M, Robinson JA: A genome scan to detect quantitative trait loci for economically important traits in Holstein cattle using two methods and a dense single nucleotide polymorphism map. J Dairy Sci 2008, 91(8):3225-3236.

3. Schennink A, Stoop WM, Visker MH, van der Poel JJ, Bovenhuis $H$, van Arendonk JA: Short communication: Genome-wide scan for bovine milk-fat composition. II. Quantitative trait loci for long-chain fatty acids. J Dairy Sci 2009, 92(9):4676-4682.

4. Stoop WM, Schennink A, Visker MH, Mullaart E, van Arendonk JA, Bovenhuis $\mathrm{H}$ : Genome-wide scan for bovine milk-fat composition. I. Quantitative trait loci for short- and medium-chain fatty acids. J Dairy Sci 2009, 92(9):4664-4675.

5. Kolbehdari D, Wang Z, Grant JR, Murdoch B, Prasad A, Xiu Z, Marques E, Stothard P, Moore SS: A whole genome scan to map QTL for milk production traits and somatic cell score in Canadian Holstein bulls. J Anim Breed Genet 2009, 126(3):216-227.

6. Jiang L, Liu JF, Sun DX, Ma PP, Ding XD, Yu Y, Zhang Q: Genome wide association studies for milk production traits in Chinese Holstein population. PLoS One 2010, 5(10):e13661.

7. Mai MD, Sahana G, Christiansen FB, Guldbrandtsen B: A genome-wide association study for milk production traits in Danish Jersey cattle using a $50 \mathrm{~K}$ single nucleotide polymorphism chip. J Anim Sci 2010, 88(11):3522-3528.

8. Cole JB, Wiggans GR, Ma L, Sonstegard TS, Lawlor TJ Jr, Crooker BA, Van Tassell CP, Yang J, Wang S, Matukumalli LK, Yang D: Genome-wide association analysis of thirty one production, health, reproduction and body conformation traits in contemporary U.S. Holstein cows. BMC Genomics 2011, 12:408.

9. Schopen GC, Visker MH, Koks PD, Mullaart E, van Arendonk JA, Bovenhuis H: Whole-genome association study for milk protein composition in dairy cattle. J Dairy Sci 2011, 94(6):3148-3158.

10. Bouwman AC, Bovenhuis H, Visker MHPW, van Arendonk JAM: Genomewide association of milk fatty acids in Dutch dairy cattle. BMC Genet 2011, 12:43.

11. Olsen HG, Hayes BJ, Kent MP, Nome T, Svendsen M, Larsgard AG, Lien S: Genome-wide association mapping in Norwegian Red cattle identifies quantitative trait loci for fertility and milk production on BTA12. Anim Genet 2011, 42(5):466-474.

12. Grisart B, Farnir F, Karim L, Cambisano N, Kim JJ, Kvasz A, Mni M, Simon P, Frère JM, Coppieters W, Georges M: Genetic and functional confirmation 
of the causality of the DGAT1 K232A quantitative trait nucleotide in affecting milk yield and composition. Proc Natl Acad Sci U S A 2004, 101:2398-2403.

13. Blott S, Kim JJ, Moisio S, Schmidt-Kuntzel A, Cornet A, Berzi P, Cambisano N, Ford C, Grisart B, Johnson D, Karim L, Simon P, Snell R, Spelman R, Wong J, Vilkki J, Georges M, Farnir F, Coppieters W: Molecular dissection of a quantitative trait locus: a phenylalanine-to-tyrosine substitution in the transmembrane domain of the bovine growth hormone receptor is associated with a major effect on milk yield and composition. Genetics 2003, 163:253-266.

14. Croucher NJ, Thomson NR: Studying bacterial transcriptomes using RNA-seq. Curr Opin Microbiol 2010, 13:619-624.

15. Marioni JC, Mason CE, Mane SM, Stephens M, Gilad Y: RNA-seq: an assessment of technical reproducibility and comparison with gene expression arrays. Genome Res 2011, 18:1509-1517.

16. Huang W, Khatib $\mathrm{H}$ : Comparison of transcriptomic landscapes of bovine embryos using RNA-Seq. BMC Genomics 2010, 11:711.

17. Cánovas A, Rincon G, Islas-Trejo A, Wickramasinghe S, Medrano JF: SNP discovery in the bovine milk transcriptome using RNA-Seq technology. Mamm Genome 2010, 21(11-12):592-598.

18. Wickramasinghe S, Hua S, Rincon G, Islas-Trejo A, German JB, Lebrilla CB, Medrano JF: Transcriptome Profiling of bovine milk oligosaccharide metabolism genes using RNA-Sequencing. PloS One 2011, 6(4):e18895.

19. Robert C, Nieminen J, Dufort I, Gagné D, Grant JR, Cagnone G, Plourde D, Nivet AL, Fournier É, Paquet É, Blazejczyk M, Rigault P, Juge N, Sirard MA: Combing resources to obtain a comprehensive survey of the bovine embryo transcriptome through deep sequencing and microarrays. Mol Reprod Dev 2011, 78(9):651-664.

20. Wickramasinghe S, Rincon G, Islas-Trejo A, Medrano JF: Transcriptional profiling of bovine milk using RNA sequencing. BMC Genomics 2012, 13:45.

21. Medrano JF, Rincon G, Islas-Trejo A: Comparative analysis of bovine milk and mammary gland transcriptome using RNA-seq. In $9^{\text {th }}$ World congress on genetics applied to livestock production. Leipzig, German, August 1-6, 2010, paper no. 0852.

22. Finucane KA, McFadden TB, Bond JP, Kennelly JJ, Zhao FQ: Onset of lactation in the bovine mammary gland: gene expression profiling indicates a strong inhibition of gene expression in cell proliferation. Funct Integr Genomics 2008, 8(3):251-264.

23. Bionaz M, Periasamy K, Rodriguez-Zas SL, Everts RE, Lewin HA, Hurley WL, Loor JJ: Old and new stories: revelations from functional analysis of the bovine mammary transcriptome during the lactation cycle. PLOS One 2012, 7(3):e33268.

24. Sun DX, Jia J, Ma Y, Zhang Y, Wang YC, Yu Y, Zhang Y: Effects of DGAT1 and GHR on milk yield and milk composition in the Chinese dairy population. Anim Genet 2009, 40:997-1000.

25. Schennink A, Stoop WM, Visher MH, Heck JM, Bovenhuis H, van der Poel Jر, van Valenberg HJ, van Arendonk JA: DGAT1 underlies large genetic variation in milk-fat composition of dairy cows. Anim Genet 2007, 38:467-473

26. Thaller G, Kramer W, Winter A, Kaupe B, Erhardt G, Fries R: Effects of DGAT1 variants on milk production traits in German cattle breeds. J Anim Sci 2003, 81:1911-1918.

27. Trapnell C, Williams BA, Pertea G, Mortazavi A, Kwan G, van Baren MJ, Salzberg SL, Wold BJ, Pachter L: Transcript assembly and quantification by RNA-seq reveals unannotated transcripts and isoform switching during cell differentiation. Nat Biotechnol 2010, 28(5):511-515.

28. Anders S, Huber W: Differential expression analysis for sequence count data. Genome Biol 2010, 11(10):R106.

29. Mortazavi A, Williams BA, McCue K, Schaeffer L, Wold B: Mapping and quantifying mammalian transcriptomes by RNA-Seq. Nat Methods 2008, 5(7):621-628.

30. Rapaport F, Khanin R, Liang Y, Pirun M, Krek A, Zumbo P, Mason CE, Socci $N D$, Betel $D$ : Comprehensive evaluation of differential gene expression analysis methods for RNA-seq data. Genome Biol 2013, 14(9):R95.

31. Hou Y, Liu GE, Bickhart DM, Matukumalli LK, Li C, Song J, Gasbarre LC, Van Tassell CP, Sonstegard TS: Genomic regions showing copy number variations associate with resistance or susceptibility to gastrointestinal nematodes in Angus cattle. Funct Integr Genomics 2012, 12(1):81-92.

32. Hou Y, Liu GE, Bickhart DM, Cardone MF, Wang K, Kim ES, Matukumalli LK, Ventura M, Song J, Vanraden PM, Sonstegard TS, Van Tassell CP: Genomic characteristics of cattle copy number variations. BMC Genomics 2011, 12:127.

33. Bagnato A, Schiavini F, Rossoni A, Maltecca C, Dolezal M, Medugorac I, Sölkner J, Russo V, Fontanesi L, Friedmann A, Soller M, Lipkin E: Quantitative trait loci affecting milk yield and protein percentage in a three-country Brown Swiss population. J Dairy Sci 2008, 91(2):767-783.

34. Arranz JJ, Coppieters W, Berzi P, Cambisano N, Grisart B, Karim L, Marcq F, Moreau L, Mezer C, Riquet J, Simon P, Vanmanshoven P, Wagenaar D, Georges M: A QTL affecting milk yield and composition maps to bovine chromosome 20: a confirmation. Anim Genet 1998, 29(2):107-115.

35. Ashwell MS, Heyen DW, Sonstegard TS, Van Tassell CP, Da Y, VanRaden PM, Ron M, Weller Jl, Lewin HA: Detection of quantitative trait loci affecting milk production, health, and reproductive traits in Holstein cattle. J Dairy Sci 2004, 87(2):468-475.

36. Zhang Q, Boichard D, Hoeschele I, Ernst C, Eggen A, Murkve B, PfisterGenskow M, Witte LA, Grignola FE, Uimari P, Thaller G, Bishop MD: Mapping quantitative trait loci for milk production and health of dairy cattle in a large outbred pedigree. Genetics 1998, 149(4):1959-1973.

37. Bennewitz J, Reinsch N, Guiard V, Fritz S, Thomsen H, Looft C, Kühn C, Schwerin M, Weimann C, Erhardt G, Reinhardt F, Reents R, Boichard D, Kalm E: Multiple quantitative trait loci mapping with cofactors and application of alternative variants of the false discovery rate in an enlarged granddaughter design. Genetics 2004, 168(2):1019-1027.

38. Pimentel EC, Bauersachs S, Tietze M, Simianer H, Tetens J, Thaller G, Reinhardt F, Wolf E, König S: Exploration of relationships between production and fertility traits in dairy cattle via association studies of SNPs within candidate genes derived by expression profiling. Anim Genet 2011, 42(3):251-262

39. Bennewitz J, Reinsch N, Grohs C, Levéziel H, Malafosse A, Thomsen H, Xu N, Looft C, Kühn C, Brockmann GA, Schwerin M, Weimann C, Hiendleder S, Erhardt G, Medjugorac I, Russ I, Förster M, Brenig B, Reinhardt F, Reents R, Averdunk G, Blümel J, Boichard D, Kalm E: Combined analysis of data from two granddaughter designs: A simple strategy for QTL confirmation and increasing experimental power in dairy cattle. Genet Sel Evol 2003, 35(3):319-338

40. Ashwell MS, Da Y, Van Tassell CP, Vanraden PM, Miller RH, Rexroad CE Jr: Detection of putative loci affecting milk production and composition, health, and type traits in a United States Holstein population. J Dairy SCi 1998, 81:3309-3314.

41. Viitala SM1, Schulman NF, de Koning DJ, Elo K, Kinos R, Virta A, Virta J, Mäki-Tanila A, Vilkki JH: Quantitative trait loci affecting milk production traits in Finnish Ayrshire dairy cattle. J Dairy Sci 2003, 86(5):1828-1836.

42. Elo KT1, Vilkki J, de Koning DJ, Velmala RJ, Mäki-Tanila AV: A quantitative trait locus for live weight maps to bovine chromosome 23. Mamm Genome 1999, 10(8):831-835.

43. Mosig MO, Lipkin E, Khutoreskaya G, Tchourzyna E, Soller M, Friedmann A: A whole genome scan for quantitative trait loci affecting milk protein percentage in Israeli-Holstein cattle, by means of selective milk DNA pooling in a daughter design, using an adjusted false discovery rate criterion. Genetics 2001, 157:1683-1698.

44. Schrooten $\mathrm{C}$, Bink MC, Bovenhuis $\mathrm{H}$ : Whole genome scan to detect chromosomal regions affecting multiple traits in dairy cattle. J Dairy Sci 2004, 87(10):3550-3560.

45. Wennemers M, Bussink J, Grebenchtchikov N, Sweep FC, Span PN TRIB3 protein denotes a good prognosis in breast cancer patients and is associated with hypoxia sensitivity. Radio Ther Oncol 2011 , 101(1):198-202.

46. Wennemers M, Bussink J, van den Beucken T, Sweep FC, Span PN: Cancer. PLoS One 2012, 7(11):e49439.

47. Qi L, Heredia JE, Altarejos JY, Screaton R, Goebel N, Niessen S, Macleod IX, Liew CW, Kulkarni RN, Bain J, Newgard C, Nelson M, Evans RM, Yates J, Montminy M: TRB3 links the E3 ubiquitin ligase COP1 to lipid metabolism. Science 2006, 312(5781):1763-1766

48. Alkafafy M, Rashed R, Helal A: Immunohistochemical studies on the bovine lactating mammary gland (Bos taurus). Acta Histochem 2012, 114(2):87-93.

49. Alkafafy M: Glycohistochemical immunohistochemical and ultrastructura studies of the bovine epididymis. In Ph.D. dissertation. Munich, Germany: Faculty of Vet. Med., LMU; 2005.

50. Zeng H, Qin L, Zhao D, Tan X, Manseau EJ, Van Hoang M, Senger DR, Brown LF, Nagy JA, Dvorak HF: Orphan nuclear receptor TR3/Nur77 regulates 
VEGF-A-induced angiogenesis through its transcriptional activity. J Exp Med 2006, 203(3):719-729.

51. Guo L, Qi ST, Miao DQ, Liang XW, Li H, Ou XH, Huang X, Yang CR, Ouyang YC, Hou Y, Sun QY, Han Z: The roles of parathyroid hormone-like hormone during mouse preimplantation embryonic development. PLoS One 2012, 7(7):e40528.

52. Onda K, Sato A, Yamaguchi M, Matsuki N, Ono K, Wada Y: Parathyroid hormone-related protein (PTHrP) and Ca levels in the milk of lactating cows. J Vet Med Sci 2006, 68(7):709-713.

53. Cros M, Cataisson C, Cho YM, Berthois Y, Bernard-Poenaru O, Denne M Graulet AM, De Vernejoul MC, Foley J, Bouizar Z: Constitutive production of parathyroid hormone-related protein (PTHrP) by fibroblasts derived from normal and pathological human breast tissue. Oncol Res 2002, 13(3):137-146.

54. Kobayashi T, Kronenberg HM, Foley J: Reduced expression of the PTH/ PTHrP receptor during development of the mammary gland influences the function of the nipple during lactation. Dev Dyn 2005, 233(3):794-803.

55. Jernas M, Palming J, Sjoholm K, Jennische E, Svensson PA, Gabrielsson BG, Levin M, Sjögren A, Rudemo M, Lystig TC, Carlsson B, Carlsson LM, Lönn M: Separation of human adipocytes by size: hypertrophic fat cells display distinct gene expression. FASEB J 2006, 20(9):1540-1542.

56. de Beer MC, Webb NR, Wroblewski JM, Noffsinger VP, Rateri DL, Ji A, van der Westhuyzen DR, de Beer FC: Impact of serum amyloid A on high density lipoprotein composition and levels. J Lipid Res 2010, 51(11):3117-3125

57. van der Westhuyzen DR, Cai L, de Beer MC, de Beer FC: Serum amyloid a promotes cholesterol efflux mediated by scavenger receptor B-I. J Biol Chem 2005, 280(43):35890-35895.

58. Kho Y, Kim S, Yoon BS, Moon JH, Kim B, Kwak S, Woo J, Oh S, Hong K, Kim $\mathrm{S}, \mathrm{Kim} \mathrm{H}$, You S, Choi Y: Induction of serum amyloid A genes is associated with growth and apoptosis of $\mathrm{HC} 11$ mammary epithelial cells. Biosci Biotechnol Biochem 2008, 72(1):70-81.

59. McDonald TL, Larson MA, Mack DR, Weber A: Elevated extrahepatic expression and secretion of mammary-associated serum amyloid A 3 (M-SAA3) into colostrum. Vet Immunol Immunopathol 2001 83(3-4):203-211.

60. Wu HJ, Luo J, Zhang LJ, Han XF, Yang BJ, Wang HB, Shan CY, Zhang N, Yu G: Cloning and sequence analysis of SAA3 gene differentially expressed in mammary gland at two lactation stages of Xinong Saanen goat. Acta Vet Zootechnica Sin 2007, 38(2):110-114.

61. Larson MA, Weber A, Webe AT, MCDonald TL: Differential expression and secretion of bovine serum amyloid $A 3$ (SAA3) by mammary epithelial cells stimulated with prolactin or lipopolysaccharide. Vet Immunol Immunopathol 2005, 107:255-262

62. Wool IG: Extraribosomal functions of ribosomal proteins. Trends Biochem Sci 1996, 21(5):164-165.

63. Jiang H, Lin JJ, Tao J, Fisher PB: Suppression of human ribosomal protein L23A expression during cell growth inhibition by interferon-beta. Oncogene 1997, 14(4):473-480.

64. Sun B, Hou YL, Hou WR, Zhang SN, Ding X, Su XL: cDNA cloning, overexpression, purification and pharmacologic evaluation for anticancer activity of ribosomal protein L23A gene (RPL23A) from the giant panda. Int J Mol Sci 2012, 13(2):2133-2147.

65. Wu X, Li Y, Xue L, Wang L, Yue Y, Li K, Bou S, Li GP, Yu H: Multiple histone site epigenetic modifications in nuclear transfer and in vitro fertilized bovine embryos. Zygote 2011, 19(1):31-45.

66. Sablina AA, Budanov AV, llyinskaya GV, Agapova LS, Kravchenko JE, Chumakov PM: The antioxidant function of the p53 tumor suppressor. Nat Med 2005, 11(12):1306-1313.

67. Budanov AV, Sablina AA, Feinstein E, Koonin EV, Chumakov PM: Regeneration of peroxiredoxins by p53-regulated sestrins, homologs of bacterial AhpD. Science 2004, 5670:596-600.

68. Alexopoulou AN, Leao M, Caballero OL, Da Silva L, Reid L, Lakhani SR, Simpson AJ, Marshall JF, Neville AM, Jat PS: Lines. Breast Cancer Res 2010, 12(4):R51.

69. Mohan HM, Aherne CM, Rogers AC, Baird AW, Winter DC, Murphy EP: Molecular pathways: the role of NR4A orphan nuclear receptors in cancer. Clin Cancer Res 2012, 18(12):3223-3228.

70. Antonescu CR, Tschernyavsky SJ, Decuseara R, Leung DH, Woodruff JM, Brennan MF, Bridge JA, Neff JR, Goldblum JR, Ladanyi M: Cases. Clin Cancer Res 2001, 7(12):3977-3987.
71. Giraldo A, Barrett OP, Tindall MJ, Fuller SJ, Amirak E, Bhattacharya BS, Sugden PH, Clerk A: Feedback regulation by Atf3 in the endothelin-1responsive transcriptome of cardiomyocytes: Egr1 is a principal Atf3 target. Biochem J 2012, 444(2):343-355.

72. Wolfgang CD, Liang G, Okamoto Y, Allen AE, Hai T: Transcriptional autorepression of the stress-inducible gene ATF3. J Biol Chem 2000, 275(22):16865-16870.

73. Suchyta SP, Sipkovsky S, Halgren RG, Kruska R, Elftman M, Weber-Nielsen M, Vandehaar MJ, Xiao L, Tempelman RJ, Coussens PM: Bovine mammary gene expression profiling using a CDNA microarray enhanced for mammary-specific transcripts. Physiol Genomics 2003, 16:8-18.

doi:10.1186/1471-2164-15-226

Cite this article as: Cui et al:: Transcriptional profiling of mammary gland in Holstein cows with extremely different milk protein and fat percentage using RNA sequencing. BMC Genomics 2014 15:226.

\section{Submit your next manuscript to BioMed Central and take full advantage of:}

- Convenient online submission

- Thorough peer review

- No space constraints or color figure charges

- Immediate publication on acceptance

- Inclusion in PubMed, CAS, Scopus and Google Scholar

- Research which is freely available for redistribution

Submit your manuscript at www.biomedcentral.com/submit
C BioMed Central 